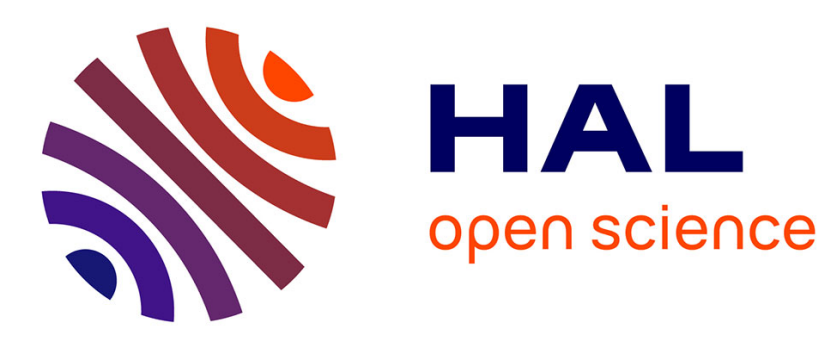

\title{
Towards the Development of a Storm Erosion EWS for the French Aquitaine Coast
}

Alexandre Nicolae Lerma, Thomas Bulteau, Héloïse Muller, Clément

Decarsin, Raphaël Gillet, François Paris, Mélanie Biausque, Nadia Senechal, Bruno Castelle

\section{To cite this version:}

Alexandre Nicolae Lerma, Thomas Bulteau, Héloïse Muller, Clément Decarsin, Raphaël Gillet, et al.. Towards the Development of a Storm Erosion EWS for the French Aquitaine Coast. Journal of Coastal Research, 2018, SI 85, 5 p. 10.2112/SI85-001.1 . hal-01719953

\section{HAL Id: hal-01719953 https: / hal-brgm.archives-ouvertes.fr/hal-01719953}

Submitted on 28 Feb 2018

HAL is a multi-disciplinary open access archive for the deposit and dissemination of scientific research documents, whether they are published or not. The documents may come from teaching and research institutions in France or abroad, or from public or private research centers.
L'archive ouverte pluridisciplinaire HAL, est destinée au dépôt et à la diffusion de documents scientifiques de niveau recherche, publiés ou non, émanant des établissements d'enseignement et de recherche français ou étrangers, des laboratoires publics ou privés. 


\title{
Towards the Development of a Storm Erosion EWS for the French Aquitaine Coast
}

\author{
Alexandre Nicolae Lerma ${ }^{\dagger *}$, Thomas Bulteau ${ }^{\ddagger}$, Héloise Muller ${ }^{\dagger}$, Clément Decarsin ${ }^{\dagger}$, Raphael Gillet ${ }^{\dagger}$, \\ François Paris ${ }^{\ddagger}$, Mélanie Biausque ${ }^{\S}$, Nadia Senechal ${ }^{\S}$, Bruno Castelle ${ }^{\S}$ \\ ${ }^{\dagger}$ BRGM (French Geological Survey), \\ Risks and Prevention Division - \\ Coastal Risks and Climate Change \\ Unit, Orléans, France, \\ ${ }^{\ddagger}$ BRGM, Regional Direction \\ Nouvelle-Aquitaine - Pessac, France, \\ ${ }^{\S}$ CNRS, University of Bordeaux, \\ UMR 5805-EPOC, OASU, Talence, \\ France
}

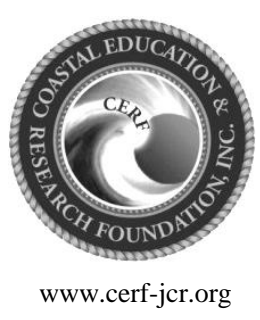

www.cerf-jcr.org

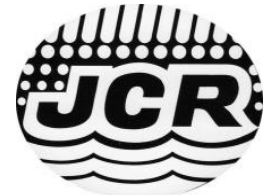

www.JCRonline.org

\begin{abstract}
Nicolae Lerma A. et al., 2018. Towards the development of a storm erosion EWS for the French Aquitanian coast. In: Shim, J.-S.; Chun, I., and Lim, H.-S. (eds.), Proceedings from the International Coastal Symposium (ICS) 2018 (Busan, Republic of Korea). Journal of Coastal Research, Special Issue No. 85, pp. 1-5. Coconut Creek (Florida),
\end{abstract} ISSN 0749-0208.

The 230-km long Aquitaine sandy coast, SW France, is vulnerable to erosion hazards owing to its full exposure to Atlantic storm waves. Since 2015, the Observatory of the Aquitaine Coast and several academic and local partners have developed a network to better survey and forecast storm-driven morphological changes at regional scale. This paper presents the implementation of an early warning system (EWS) with the primary objective to alert the network members 2-3 days ahead in order to perform pre-storm and post-storm surveys. Regional bulletins are edited to identify the most exposed coastal sections. At local scale, tests are realized on two morphological indicators used to forecast qualitatively and quantitatively the likelihood of beach and dune erosion. The two indicators (namely the Collision Regime Indicator, CRI, and the Eroded Volume Indicator, EVI, were calibrated and further validated at two nearby beaches where extensive morphological data are collected regularly: bimonthly surveys from 2009 to 2015 at Truc Vert beach and surveys every 2 to 7 days during the winters since 2015 at Biscarrosse beach. Results indicate promising performance, with the CRI predicting collision regime when front dune erosion was indeed observed, and the EVI predicting fairly accurate eroded sediment volume on cross shore beach profile. Nevertheless, more extensive validation of the $\mathrm{CRI}$ and EVI is needed to extend the indicators to the entire Aquitaine coast and for a wide range single storms and storm clusters.

ADDITIONAL INDEX WORDS: Impact forecast, Beach survey, Collision regime, Eroded volume, Vigilance erosion network

\section{INTRODUCTION}

The majority of the coasts around the world are affected by erosion (Brid 1985). Sandy coasts are particularly mobile and vulnerable, suffering in many cases the impact of seasonal storms in a context of long term sand supply deficits. Facing the increased population living in coastal areas, a better understanding and anticipation of the consequences of storms in terms of erosion are of paramount importance for security, crisis management action and for planning coastal development in the context of climate change. The first goal of erosion early warning system (EWS) is to provide relevant information, early enough before a storm, to anticipate the hazard and possibly take action to minimize the risk for the exposed population. Two main kinds of warning systems can be developed, focusing on hydrodynamic conditions only (e.g. Dube et al., 2009 ; Morrow et al., 2014 ; Stephens and Cloke, 2014) or forecasting hydrodynamic conditions and impacts like the CoSMoS System in California, (Barnard et al., 2014), the USGS system in USA eastern coast or the Emilia-Romagna system (Harley et al., 2016). Depending on the particularities of the coastal morphology and the storm characteristics, these systems provide various levels of information for the scientific community as well as for stakeholders and policy makers.

The 230-km long Aquitaine coast (Figure 1), SW France, is vulnerable to erosion hazards owing to its full exposure to Atlantic storm waves. During the winter 2013-2014, due to an exceptional succession of storms with the highest winter-mean wave energy since at least 1948 (Masselink et al., 2016), almost $40 \%$ of the Aquitaine coast were affected by substantial erosion, with shoreline retreat locally exceeding $20 \mathrm{~m}$ (Bulteau et al., 2014).

Since 2015, the Observatory of the Aquitaine Coast (OCA) and several academic and local partners have developed a network to better survey and forecast storm-driven morphological changes at regional scale. The activity of this network, called "vigilance erosion", is linked to the development of an integrated EWS, the main goal being to forecast storm event erosion impacts, early enough to be able to anticipate and organize pre and post storm beach morphology surveys on the field. All collected data are stored and analyzed to further study the relationship between meteocean conditions and morphological beach response ain order to ultimately improve forecasting methods. The action of the Aquitaine vigilance 
erosion network is to support coastal risks research activities but also to provide adapted information for stakeholders such as technical services of local cities. After describing the data and methods used to forecast erosion potential impact on the Aquitaine coast, we present the information provided by the EWS through the tests and implementation of synthetic indicators. Results are subsequently presented and further discussed before conclusions are drawn.

\section{DATA AND METHODS}

The Aquitaine EWS aims at forecasting static and dynamic water levels and elaborating synthetic indicators at various spatial scales related with local storm surge conditions, wave conditions and geomorphological characteristics of the coast.

\section{Hydrodynamic data}

Tide and atmospheric surge data are collected from the MARC platform (Modelling and Analysis for Research in Coastal environment, www.umr-lops.org/marc), more precisely from the structured domain covering the whole Aquitanian coast with a spatial resolution $(\Delta \mathrm{d})$ of $250 \mathrm{~m}$.

Numerical simulations are operated by IFREMER with the MARS2DH model (Lazure and Dumas, 2008). To reproduce tidal variations the Aquitaine nested grid is forced with 143 tidal components supplied by SHOM (CST-France data base). To simulate the storm surge, meteorological forecast forcing comes from ARPEGE and AROME of Meteo-France (Seity et al., 2011). The performance of the modeling chain was extensively validated at 19 tide gauges and 95 current meters in PineauGuillou (2013). Data are extracted every $15 \mathrm{~min}$ at the most nearshore valid location every 5 kilometers along the coast along the 10-m depth isobaths. The reference datum is the mean sea level (MSL), requiring a spatially-variable vertical correction (RAM, 2016) to convert the results into the local topographic datum (IGN69).

\section{Wave data}

Wave data are also extracted from the MARC platform but from an unstructured domain with $\Delta \mathrm{d}$ approx. $200 \mathrm{~m}$ at the coast. Simulations are operated by the IFREMER with the WW3 model (Tolman, 2009). Data are extracted every $1 \mathrm{~h}$ along the 50-m depth isobath in front of the water level extraction point. At each location, the wave energy density per length unit of wave crest and over a given period of time is estimated as:

$$
\sum E=\int_{0}^{N} \frac{1}{16} \rho g H_{S}^{2} \Delta t
$$

with $\rho$ : the density of sea water, $1030 \mathrm{~kg} / \mathrm{m} 3 ; g$ : the gravitational acceleration, $9.81 \mathrm{~m} / \mathrm{s}^{2} ; H s$ : significant wave height, $\Delta t$ : time step ; $N$ : the considerate time in hours

\section{CRI estimation}

The Collision Regime Indicator (CRI) is an adaptation of the Safe Corridor Width defined by Harley et al. (2016). It estimates the expected hydrodynamic regime (swash or collision regime) on the beach/dune system from the local dynamic water level and morphological parameters (beach slope, dune foot height). At local scale, still water level $\left(\boldsymbol{\eta}_{\boldsymbol{s}}\right)$, static water level $\left(\boldsymbol{\eta}_{\boldsymbol{s}}\right)$, and dynamic water level $\left(\boldsymbol{\eta}_{\boldsymbol{d}}\right)$ are estimated at each time step as follows:

$$
\begin{gathered}
\boldsymbol{\eta}_{\boldsymbol{s}}=\text { Tide + Atmospheric Surge } \\
\boldsymbol{\eta}_{\boldsymbol{s}}=\text { Tide + Atmospheric Surge + Wave setup } \\
\boldsymbol{\eta}_{\boldsymbol{d}}=\text { Tide + Atmospheric Surge + Run up2\% }
\end{gathered}
$$

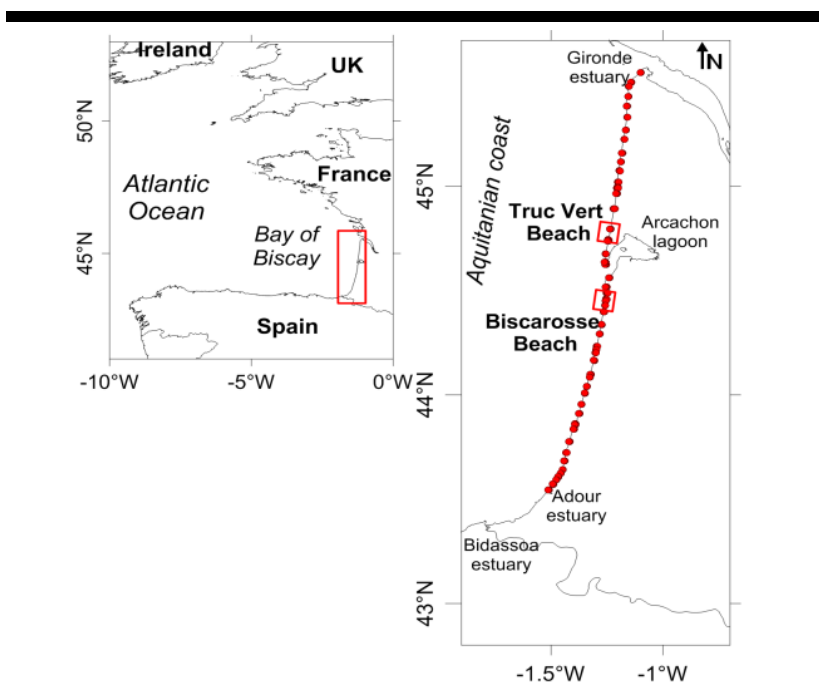

Figure 1. Location of the Aquitaine Coast (left) and location of the study site (right). The red points indicate the OCA profiles network

Wave setup and runup are estimated using the parametric formulas proposed by Stockdon et al. (2006) and the local beach profile characteristics. The application of the appropriate formula is based on a preliminary assessment of the hydromorphodynamic context (dissipative, intermediate or reflective) through the calculation of the Iribarren number:

$$
\xi_{0}=\frac{\boldsymbol{\beta}}{\left(\frac{H_{S}}{L_{o}}\right)^{1 / 2}}
$$

with $\beta$ : beach slope calculated on the profile between $\boldsymbol{\eta}_{\boldsymbol{s} \boldsymbol{t}}$ and the dune foot $\left(\boldsymbol{D}_{\boldsymbol{f}}\right.$, cf. Figure 2$) ; H s(\mathrm{~m})$ : significant wave height in deep water; $L o(\mathrm{~m})$ wavelength in deep water.

The CRI is calculated hourly and evaluates the cross shore distance in meters between the horizontal position of the intersection of $\boldsymbol{\eta}_{\boldsymbol{d}}$ and the profile $\boldsymbol{\eta}_{\boldsymbol{d}, \boldsymbol{x}}$ and the horizontal position of $\boldsymbol{D}_{\boldsymbol{f}}$ :

$$
\text { CRI }=\boldsymbol{\eta}_{\boldsymbol{d}, \boldsymbol{x}}-\boldsymbol{D}_{\boldsymbol{f}, \boldsymbol{x}}
$$

As the profiles are changing over time, the positions of $\boldsymbol{D}_{\boldsymbol{f}}$ and $\boldsymbol{\eta}_{\boldsymbol{d}}$ must be regularly updated so that the CRI gives reliable results.

To identify the hydrodynamic regime, and therefore the potential impacts in terms of erosion, the typology proposed by Sallenger (2000) is used. We considered the regime as :

- Swash regime if $\boldsymbol{\eta}_{\boldsymbol{d}}<\boldsymbol{D}_{\boldsymbol{f}}$, potential morphological changes are limited to the beach.

- Collision regime if $\boldsymbol{\eta}_{\boldsymbol{d}}>\boldsymbol{D}_{\boldsymbol{f}}$, potential morphological changes are expected to affect the beach and the dune front. 
- Overwash regime if $\boldsymbol{\eta}_{\boldsymbol{d}}>\boldsymbol{D}_{\boldsymbol{t}}$ (top of the dune), potential morphological changes are expected to affect the beach and the entire dune. Nevertheless, due to the typical morphology of the dune along the Aquitaine open coast (generally higher than $10 \mathrm{~m}$ and reaching more than 20 $\mathrm{m}$ in some areas), the overwash regime appears to be very unlikely (Bulteau et al., 2016)

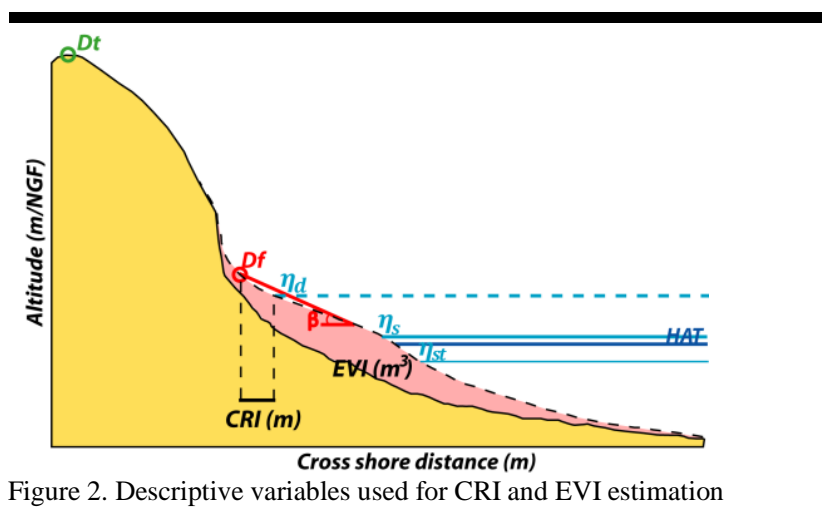

Figure 2. Descriptive variables used for CRI and EVI estimation

\section{EVI estimation}

As preliminary development, the relevance of a second complementary local indicator is tested. The potential Eroded volume indicator (EVI) provides an estimation of the stormdriven eroded volume of sediment from the offshore wave energy density and the pre-storm beach profile volume inspired from Splinter et al. (2014). It considers a relationship between eroded volumes and the wave energy (as previously described) released on the upper part of intertidal beach (when $\boldsymbol{\eta}_{\boldsymbol{d}}$ exceeds the local HAT level, Figure 2).

\section{Topo bathymetric data}

Morphological beach profile data are exploited from several databases: i) Annual survey of beach morphology at more than 50 sites along the Aquitaine coast (cf. Figure 1) from the Aquitaine Coast Observatory (OCA); ii) Bimonthly beach surveys performed at Truc Vert since April 2003 (Castelle et al., 2014, 2015); iii) irregular high-frequency ( weekly) surveys at Biscarrosse beach, becoming more frequent during winters at the scale of the storm response since 2015 (Biausque et al., 2016).

\section{RESULTS}

The Aquitanian EWS produce several complementary information at various spatial scales, from regional to local, aiming at alerting about the incoming occurrence of an erosive episode that might affect the Aquitanian coast.

\section{Regional scale}

Alerts at regional scale are based on forecast data to determine a level of potential impact. Three criteria are considerate $\eta_{s t}, H s$, $T p$ regarding specific threshold for each one. Regional bulletin (cf. Figure 3) are sent to the network partners when at least 2 thresholds are exceeded for minimum one location along the coast. For storm conditions, it gives spatialized information of potential impact along the coast.

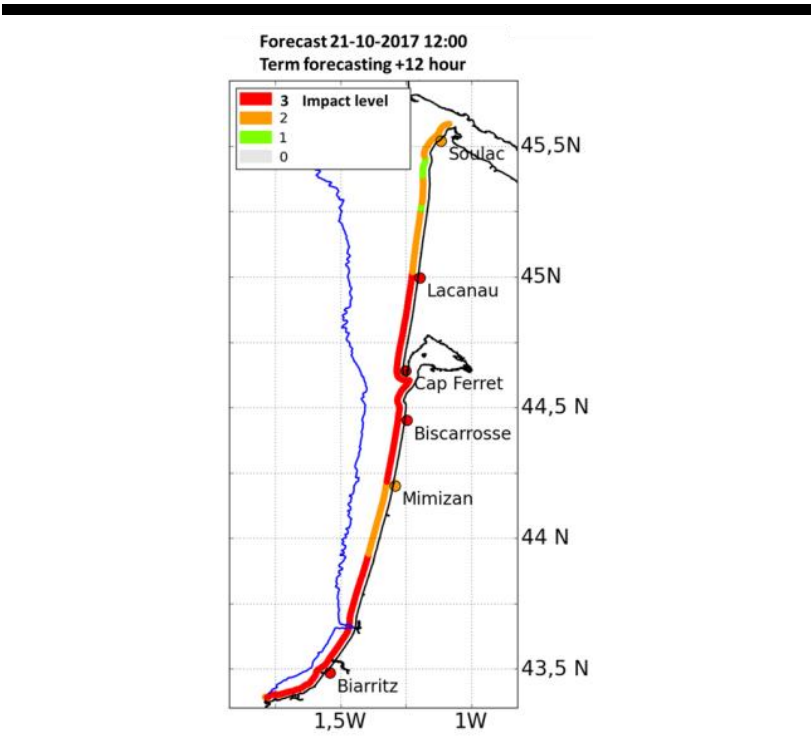

Figure 3. Example of a regional bulletin 12 hour before the storm

\section{Local scale}

The CRI indicates the potential occurrence of a collision regime. It was implemented at Biscarrosse beach in order to evaluate its performance at local scale during 2 erosive events during the 2016 winter, where the front dune erosion was observed. Just one event is illustrated and detailed here but the other observed sequence presents similar results and conclusion. Considering a cross shore profile, the determination of the exact location of the dune foot can be difficult because a clear break in slope is not evident (Figure 4).

To relate dune foot retreat and instantaneous dynamic water level reached during the event, we consider 3 different altitudes for the dune foot $(4,5$ and $6 \mathrm{~m} / \mathrm{NGF})$. Note that an analysis of the entire OCA profiles database showed that the dune foot in the whole Aquitaine coast is observed between 4 and $6 \mathrm{~m} / \mathrm{NGF}$ and it is commonly observable at $5 \mathrm{~m} / \mathrm{NGF}$.

During the illustrative sequence (Figure 5), the 4,200-m spaced profiles show a quasi-homogenous cross-shore retreat:

$$
\begin{array}{ll}
\text { - } & 10 \text { to } 13 \mathrm{~m} \text { at } 4 \mathrm{~m} / \mathrm{NGF} \\
\text { - } & 5 \text { to } 7 \mathrm{~m} \text { at } 5 \mathrm{~m} / \mathrm{NGF} \\
& 0.5 \text { to } 3 \mathrm{~m} \text { at } 6 \mathrm{~m} / \mathrm{NGF}
\end{array}
$$

The CRI indicates that during the storm sequence $\boldsymbol{\eta}_{\boldsymbol{d}}>\boldsymbol{D}_{\boldsymbol{f}}$ for $\boldsymbol{D}_{\boldsymbol{f}}=4 \mathrm{~m}$ and $5 \mathrm{~m} / \mathrm{NGF}$. Collision regime is reached 7 times for $\boldsymbol{D}_{\boldsymbol{f}}=4 \mathrm{~m}$ and 3 times for $\boldsymbol{D}_{\boldsymbol{f}}=5 \mathrm{~m}$. When the CRI indicates a collision regime, a front dune retreat is indeed observed. We also observe that a dune foot retreat occurs when CRI $<5 \mathrm{~m}$.

Based on these results at the scale of the event and on the work of Castelle et al. (2017) who used a similar approach showing that the Total Water Level $\left(\right.$ TWL $\left.\approx \boldsymbol{L}_{\boldsymbol{i}}\right)$ is a good indicator of the dune retreat when the dune foot elevation is exceeded, we hypothesize that the CRI is a relevant proxy to identify time windows prone to front dune erosion.

To investigate the relationship between wave energy and storm-driven eroded volume, the data collected at Truc Vert beach are analyzed during the period covering 2009-2013 (39 
erosive storm events) and the performance of the EVI is evaluated on the 2013-2015 period (13 events), including the extreme storms of the winter 2013-2014.

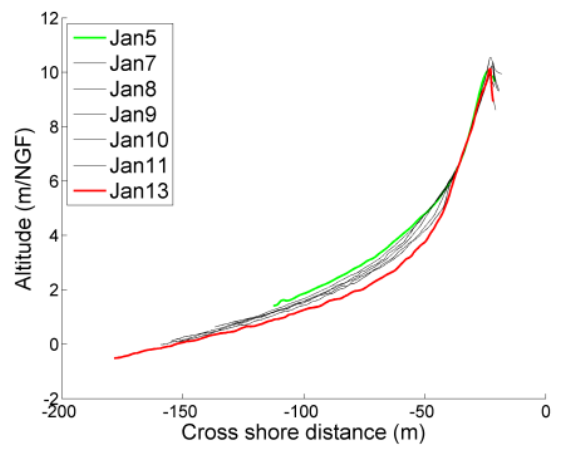

Figure 4. Beach profile evolution during the January sequence at Biscarrosse beach

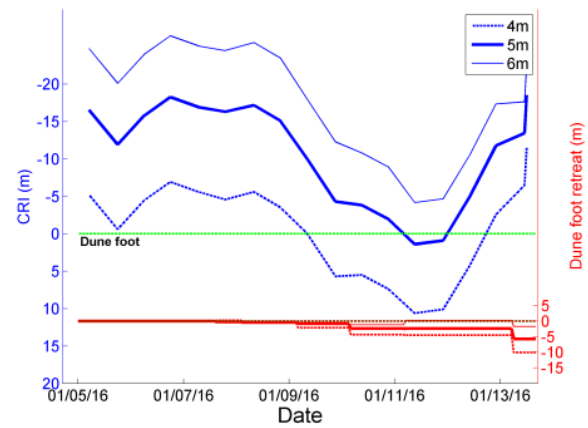

Figure 5. Estimation of the CRI in a cross shore profile during the January sequence at Biscarrosse. The lines represent the maximum values of the CRI obtained at each high tide for several dune foot $\left(\boldsymbol{D}_{\boldsymbol{f}}\right)$ altitudes relative to the horizontal position of the dune foot (green line). On the right axis, the observed horizontal retreat of the dune foot for each altitude is represented.

The results are of varying quality and among all the approaches we tested, the one that best reproduces eroded volumes (considerate along the entire cross shore profile), over the 2014-2015 periods is based on two linear models depending on the available sand prone to be eroded. The first model is applied if the pre-storm profile is already eroded, the second is applied for supplied pre-storm profile. The state of the profile is determined comparing the available pre-storm profile with the inter-seasonal typical mean profile. This mixed model presents interesting performances $\left(\mathrm{R}^{2}=0.83\right.$; RMSE $=7.7 \mathrm{~m}^{3} / \mathrm{m}$; NRMSE $=22 \%$ ). Nevertheless, it requires a pre-storm profile and a multiannual and multi-seasonal survey long enough to establish a mean profile representative of seasonal variability. A simpler approach without consideration of the pre-storm morphologic state of the profile, leads to less reliable results, with $\left(\mathrm{R}^{2}=0.70\right.$; RMSE $=10.3 \mathrm{~m}^{3} / \mathrm{m}$; NRMSE $=23 \%$, Figure 6).

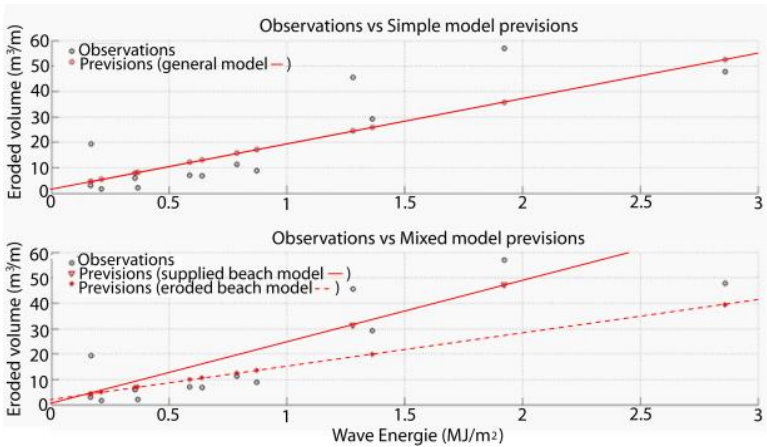

Figure 6. Comparison between eroded volume and estimated volume for the 2014-2015 storm events

\section{DISCUSSION}

The Aquitanian EWS system is based on forecast data, so the good predictions are closely dependent on the accuracy of the hydrodynamic predictions. In order to evaluate the potential error of the CRI prediction, a sensitivity analysis on forcing variables was conducted, looking at CRI changes as $H s, T p$ and $\boldsymbol{\eta}_{\boldsymbol{s}}$ vary by $+/-10 \%$ during the two studied erosive events at Biscarrosse (winter 2015-2016).

In summary, the variation of the static water level $\left(\boldsymbol{\eta}_{\boldsymbol{s t}}+/\right.$ $10 \%$ ) leads to a variation of the CRI of $+/-3 \mathrm{~m}$ (cross shore distance between $\boldsymbol{\eta}_{\boldsymbol{d}}$ and $\boldsymbol{D}_{\boldsymbol{f}}$ ), the peak period $(T p+/-10 \%)$ of $+/-2 \mathrm{~m}$ and the significant wave height $(H s+/-10 \%)$ of $+/-1 \mathrm{~m}$. The water level and the peak period therefore have a greater influence on the calculation of the indicator than the significant wave height. However, potential errors do not change notably the CRI results and therefore appear to be manageable.

Uncertainties concerning the beach slope have a poor effect on the CRI results mostly because in case of storm conditions, the Iribarren number indicates systematically dissipative hydrodynamic regimes. In this condition, the appropriate equation for determining $\boldsymbol{\eta}_{\boldsymbol{d}}$ does not take into account the beach slope and runup predictions are based only on offshore hydrodynamic conditions. In some cases, at the intensification of wave conditions (at the beginning of a storm event), we can note a change from intermediate to dissipative regime and, in turn, a sudden change of the CRI prediction (higher than $10 \mathrm{~m}$ ), but they do not affect the performance of the CRI.

Results about the implementation of the CRI indicate that it can be an interesting proxy to alert about erosive events impacting the dune front. Nevertheless, some events can impact more specifically the intertidal beach and some others can rather impact the dune. These two types of events should be detected. To deal with this, a basic intensity scale inspired by the results (cf. Figure 5) and observations on the field is proposed in order to classify the potential intensity of the impact. This scale is based on the CRI and $\boldsymbol{\eta}_{\boldsymbol{d}}$, identifying 4 alert levels associated with expected impacts on the field (see table 1). This scale is used as a first approximation of the local dune foot elevation which, based on the OCA profiles database, is most of the time around $5 \mathrm{~m}$ NGF. 


\begin{tabular}{|c|c|c|c|c|}
\hline \multicolumn{5}{|c|}{ Table $\mathrm{N}^{\circ} 1:$ CRI alert levels } \\
\hline & Level 1 & Level 2 & Level 3 & Level 4 \\
\hline CRI & $\begin{array}{c}\text { Swash } \\
\text { regime }\end{array}$ & $\begin{array}{c}\text { Swash } \\
\text { regime }\end{array}$ & $\begin{array}{c}\text { Collision } \\
\text { regime }\end{array}$ & $\begin{array}{l}\text { Collision } \\
\text { regime }\end{array}$ \\
\hline$\eta_{d}$ & $<4 \mathrm{~m}$ & $\begin{array}{c}4 \mathrm{~m} \text { to } \\
5 \mathrm{~m}\end{array}$ & $\begin{array}{c}5 \mathrm{~m} \text { to } \\
6 \mathrm{~m}\end{array}$ & $>6 \mathrm{~m}$ \\
\hline $\begin{array}{l}\text { Potentie } \\
1 \text { Impact }\end{array}$ & $\begin{array}{c}\text { No } \\
\text { significa } \\
\text { nt } \\
\text { impact }\end{array}$ & $\begin{array}{l}\text { Digging } \\
\text { of the } \\
\text { beach } \\
\text { profile }\end{array}$ & $\begin{array}{l}\text { Dune } \\
\text { front } \\
\text { retreat }\end{array}$ & $\begin{array}{c}\text { Major } \\
\text { erosion } \\
\text { on the } \\
\text { dune }\end{array}$ \\
\hline
\end{tabular}

\section{CONCLUSIONS}

The primary objective of the Aquitaine erosion EWS is to alert 2-3 days ahead the "vigilance erosion" network members by providing adapted information to perform pre-storm and post-storm morphological surveys. Ultimately, it will be used to activate local plan to mitigate the impacts of a potential erosive events and to protect the population.

Two levels of information are provided, general information of the most exposed coastal sectors at regional scale and specific information concerning the expected impact intensity at local scale. At this stage, the CRI was implemented successfully but calibration and validation of the local indicators were limited and more extensive validation is needed to generalize these estimations for the entire Aquitaine coast. Future developments will systematically improve the methods in order to consider a wider range of storms and storm clusters or to integrate more detailed hydro-morphodynamic modelling. The Aquitaine erosion EWS is expected to be further developed and improved as a result of the needs and feedbacks of from the network partners.

\section{ACKNOWLEDGMENTS}

The authors are grateful to the all 'vigilance erosion' network partners: ONF, EPOC, SIAME, ERMMA, LIENSs; and cofunding of the project: Region Nouvelle Aquitaine, UE, OASU and BRGM. BC funded by SONO (ANR-17-CE01-0014).

\section{LITERATURE CITED}

Barnard, P. L., van Ormondt, M., Erikson, L.H., Eshleman, J., Hapke, C., Ruggiero, P., Adams, P. N., and Foxgrover, A. C., (2014) Development of the Coastal Storm Modeling System (CoSMoS) for predicting the impact of storms on high-energy, active-margin coasts. Natural Hazards, 31 p.,

Bird E.C.F. 1985. Coastline Changes: A Global Review. John Wiley and Sons, Chichester, $219 \mathrm{pp}$

Biausque M., Senechal N., and Barre A. 2016. Réponse d'une plage sableuse aux événements de tempête : variabilité longshore et impacts d'ouvrages -XIV èmes Journées Nationales Génie Côtier-Génie Civil, Toulon,

Bulteau T., Mugica J., Mallet C., Garnier C., Rosebery D. Maugard F., Nicolae Lerma A., Nahon A. and Millescamps B. 2014. Evaluation de l'impact des tempêtes de l'hiver 2013-2014 sur la morphologie de la côte Aquitaine. Rapport final BRGM/RP-63797-FR, 68p.

Bulteau T., Nicolae Lerma A., and Mugica J., 2016. Caractérisation de l'exposition du littoral Aquitain à l'aléa submersion marine. Rapport final. BRGM/RP-63802-FR
Castelle B, Marieu V., Bujan S., Ferreira S., Parisot J-P., Capo S., Sénéchal and N., Chouzenoux T. 2014. Equilibrium shoreline modelling of a high-energy meso-macrotidal multiple-barred beach. Marine Geology, vol. 347, p. 85-94.

Castelle, B., Marieu, V., Bujan, S., Splinter, K.D., Robinet, A., Senechal, N., and Ferreira, S., 2015. Impact of the winter 2013-2014 series of severe western Europe storms on a double-barred sandy coast: beach and dune erosion and megacusp embayments. Geomorphology 238, 135-148

Castelle B., Bujan, S., Ferreira, S., and Dodet, G., 2017. Foredune morphological changes and beach recovery from the extreme 2013/2014 winter at a high-energy sandy coast. Marine Geology 385, 41-55

Dube SK, Jain I, Rao AD, and Murty TS (2009) Storm surge modelling for the Bay of Bengal and Arabian Sea. Natural Hazards 51: 3-27

Harley, M.D., Valentini, A., Armaroli, C., Perini, L., Calabrese, L. and Ciavola, P., 2016. Can an early-warning system help minimize the impacts of coastal storms? A case study of the 2012 Halloween storm, northern Italy. Nat. Hazards Earth Syst. Sci., 16, 209-222.

Lazure P., and Dumas F., 2008. An external-internal mode coupling for a 3D hydrodynamical model for applications at regional scale (MARS). Advances in Water Resources 31, 233-250.

Masselink, G., Castelle, B., Scott, T., Dodet, G., Suanez, S., Jackson, D., and Floc'h, F. (2016). Extreme wave activity during 2013/2014 winter and morphological impacts along the Atlantic coast of Europe. Geophys. Res. Lett. 43 (5), 2135-2143.

Morrow, B. H., J. K. Lazo, J. Rhome, and J. Feyen, (2015) Improving storm surge risk communication: Stakeholder perspectives. Bulletin of the American Meteorological Society, 96, 35-48, doi:10.1175/BAMS-D-13-00197.1.

Pineau-Guillou Lucia (2013). PREVIMER. Validation des atlas de composantes harmoniques de hauteurs et courants de marée. ODE/DYNECO/PHYSED/2013-02.

RAM (2016). Références Altimétriques Maritimes. Ports de France métropolitaine et d'outre-mer. Côtes du zéro hydrographique et niveaux caractéristiques de la marée. $120 \mathrm{p}$.

Sallenger, A., H., Jr., (2000). Storm Impact Scale for Barrier Islands. Journal of Coastal Research, 16, (3), p. 890-895.

Seity, Y., Brousseau, P., Malardel, S., Hello, G., Bénard, P., Bouttier, F., and Masson, V. (2011). The AROME-France convective-scale operational model. Monthly Weather Review, 139(3), 976-991.

Stephens, E. and Cloke, H. (2014) Improving flood forecasts for better flood preparedness in the UK (and beyond). Geographical Journal, 180 (4). pp. 310-316.

Stockdon, H.F., Holman, R.A., Howd, P.A., and Sallenger, A.H., (2006). Empirical parameterization of setup, swash, and runup. Coast. Eng. 53 (7), 573-588.

Tolman, H. L. (2009) User Manual and System Documentation of WAVEWATCH III version 3.14, Technical Report 276, NOAA/NWS/NCEP/MMAB. 